\title{
WHAT DO ANCIENT HISTORIANS MAKE OF THE NEW TESTAMENT?
}

\author{
Alanna Nobbs
}

\begin{abstract}
Summary
This article looks at some of the ways in which ancient historians, such as A. N. Sherwin-White, E. A Judge and A. H. M. Jones, use Acts and other parts of the New Testament as historical sources, in the same way that they use other ancient sources such as Herodotus, Thucydides and Tacitus. They do not use the New Testament uncritically, but take account of its individual authors and particular circumstances. Comparison is made to the ways in which some classical authors have been used for similar purposes.
\end{abstract}

In the 1960s this would have seemed a novel question, prompting some to see it as not even worth asking. Since then much of the scholarship on the Roman Empire and as especially on Late Antiquity has focused on the influence of Christianity and the conjunction of the classical and Christian within it. Tertullian's provocative question 'What has Athens to do with Jerusalem?' has spawned a wealth of answers from his own day till this.

German scholarship, in its conjunction of Antike und Christentum, had long been the acknowledged leader in the field. In the 1960s there appeared two works which arguably were seminal in provoking English-language classical scholars and Neutestamentler to pay closer attention to each others' research. If this has still not gone far enough, in the coming generation we may hope for increasing dialogue.

In 1963 when A. N. Sherwin-White's Roman Society and Roman Law in the New Testament appeared, it was seen in English- speaking, and probably in German circles too to a lesser extent, as truly 
groundbreaking. ${ }^{1}$ It attracted around twenty reviews largely by eminent reviewers, in all the major Classical periodicals published in Britain, USA, Germany, France, Holland, Belgium and Italy; and somewhat tellingly was more noticed by them than by New Testament publications, though by no means ignored by the latter. Sherwin-White was of course well known as a classicist and teacher at Oxford and had in 1939 published a definitive work on Roman citizenship which won the Conington Prize. He was already known too as a frequent contributor to major periodicals such as the Journal of Roman Studies, and was to go on to be President of the Roman Society from 1974-77, and a foremost commentator on Pliny and expert on Roman foreign policy.

Roman Society and Roman Law is a small book, which began as the Sarum lectures for 1960-61, and was never meant to be a comprehensive treatment of so vast a topic. John Crook, reviewing the book not uncritically for Classical Review, ${ }^{2}$ remarked of Acts that it is 'an historical source talking about exactly the same world as Tacitus and Suetonius', and judged that Sherwin-White's 'first six lectures combine to support the authenticity in detail of Acts' (not all detail is necessarily implied in that, by the way). Nor is he willing to accept that the Gospel writers are, as Sherwin-White would have it, comparable to Herodotus in the way they use 'their story as a vehicle of a moral or religious idea'. Interestingly the Cambridge-educated J. J. Nicholls, a long-standing lecturer in Roman History at the University of Sydney, and one who was generally not sympathetic to notions of Christian influence, regards as 'probably correct' Sherwin-White's argument (contra the form critics) that the Gospels/Acts 'are to be treated as equally serious and valuable evidence' as Herodotus, Thucydides and Tacitus. ${ }^{3}$ In the Journal of Roman Studies, ${ }^{4}$ Henry Chadwick (again, not an uncritical reviewer), sees the true significance of the book in the criticism and correction, from a Roman historian's standpoint, of the work of theologians, in particular of Lietzmann and Cadbury.

1 A. N. Sherwin-White, Roman Society and Roman Law in the New Testament (Oxford: Oxford University, 1963). I am grateful to Rachel Yuen-Collingridge for bibliographical assistance for this article.

2 Classical Review 14 (1964): 198-200.

3 J. J. Nichols in Journal of Religious History (1964): 92-5.

4 Journal of Roman Studies LV (1965): 276-7. 
The European scholar Raubitscheck, by then at Stanford, was far more convinced. "The silence of the ancient historians about the "greatest story" is comparable to the ignorance of its modern interpreters of the achievements of ancient history: Cadbury should study Jones just as Tacitus should have studied the New Testament. ${ }^{5}$ No firmer endorsement could have been forthcoming though, and not all would want to go along that path!

There is no further need to show that Sherwin-White's book in a sense legitimised, for the British scholarly establishment at least, some engagement between the worlds of the New Testament and of Classics.

A little earlier, the Hulsean prize-winning essay of E. A Judge at Cambridge had been published in 1960 as The Social Pattern of the Christian Groups in the First Century: Some Prolegomena to the Study of New Testament Ideas of Social Obligation. ${ }^{6}$ In it, Judge stated the view he has maintained throughout a scholarly lifetime, that 'modern scholars have created for themselves the problems of New Testament acquiescence and inconsistency, through neglecting to identify the situation to which the New Testament writings were actually addressed.' He goes on to point out that the New Testament is 'a heterogeneous collection of writings addressed to various occasions', and that failing to note the particular situation 'may result in imprecision'. In the view of some, Judge has founded a schola in the best classical sense, ${ }^{7}$ and his works have been influential in the United States and beyond, in encouraging and promoting the integration of classical/ancient historical and New Testament scholarship.

This brief study can do no more than look at a few examples of the way a selection of subsequent classically trained ancient historians has seen fit to juxtapose classical and New Testament texts in the service of ancient history and of illuminating the world in which Christianity grew and developed.

A. H. M. Jones, writing in some cases after Sherwin-White but not of course his junior, used both New Testament and classical authors in his Studies in Roman Government and Law (a collection of earlier

5 Classical Weekly LVI (1963): 294.

6 Published by Tyndale e.g.. The essay had been the Tyndale New Testament lecture for 1958, and was awarded the Hulsean Prize in 1959.

7 E.g. Bruce W. Winter, Philo and Paul among the Sophists, (2nd ed.; Grand Rapids: Eerdmans, 2002): xiv. 
published titles collected together in 1960). ${ }^{8}$ Looking at the right of a Roman citizen to appeal to Caesar, he takes up the case of Paul. After discussing Paul's appeal during his hearing before Festus from the evidence solely of Acts, Jones concludes: 'From the facts it would seem that a Roman citizen was protected against arbitrary flogging without trial and if accused could refuse to submit to trial by appealing to Caesar'. Now Jones was not in other cases uncritical of the evidence of Acts, but what is instructive is his willingness to use it as a source for the practices of the times to which it refers: in other words to treat it as any ancient historian treats the sources he or she has determined, with whatever caveats, are appropriate to what is under discussion.

The immediate past holder of the Camden Chair of Ancient History at the University of Oxford, Fergus Millar, has likewise integrated (though again never uncritically) Acts and other Graeco-Roman evidence in a variety of contexts. In The Emperor in the Roman World (31 BC-AD 337) (1977), ${ }^{9}$ he sets the evidence of Dio alongside that of Acts in a discussion of the same circumstance as Jones deals with; namely the right of appeal to the emperor. The appeal of Paul he calls an 'actual instance' (in other words showing a preparedness to accept the outline of the Acts story), though he is doubtful whether Acts can be used to substantiate the legal basis of such an appeal. So too, without accepting Acts as a source for Roman Law, and citing a comparable case from Dio, he acknowledges that the narrative of Acts tells us 'a lot about the power of the name of Caesar in the minds both of his subjects and of his appointees'.

One final example will suffice to show that the New Testament is taken as seriously (in the sense of being discussed and analysed in relation to a particular historical problem) as classical works by practising ancient historians comes from Stephen Mitchell in his Anatolia: Land Men and Gods in Asia Minor (1993). Here, Acts and Galatians are examined in the context of determining the geography and history of the region. While 'the absolute chronology of Paul's missions has been much discussed' and 'many questions of detail will remain unresolved', Mitchell nevertheless uses both Acts and Galatians as basic sources for his account.

\footnotetext{
${ }^{8}$ A. H. M. Jones, Studies in Roman Government and Law (Oxford: Blackwell, 1960)

${ }^{9}$ Fergus Millar, The Emperor in the Roman World (London: Duckworth, 1977).
} 
To turn now to a couple of works which may be held to be more directly indebted to Judge's influence, the interchange between ancient historians and New Testament scholars can be seen to be operating at a finely-tuned level.

The six-volume series The Book of Acts in its First Century Setting was conceived by Bruce Winter, though different volumes were edited by others. It is a fitting time to draw attention to his overseeing of that series and to the impact it has produced, largely because of its having such a variety of authors and perspectives brought into the compass of the volumes.

Most instructive for the ancient historian is the reflection on Sallust. ${ }^{10}$ For the Catilinarian conspiracy we have essentially the same range of sources, mutatis mutandis, as we have for the time of Paul: letters from a protagonist, who is of course partisan; and a narrative account from a contemporary (allowing that to be the case for Acts at least in the sense that it must use contemporary evidence), who was in some sense involved in the proceedings, and so has both a purpose in writing and a stake in the reader's verdict. Much the same holds for the reign of Julian, where we do have more in the way of sources but essentially rely on Julian's own writings together with the narrative of his contemporary Ammianus Marcellinus. Yet an ancient historian would not disregard any of this evidence, but would rather interpret and construe it according to his/her historical principles and judgement, both in general and in each individual case. It is probably fair comment that for most periods in Greek and Roman history ancient historians would kill (well ... almost!) for the sort of evidence represented by Acts and the Pauline corpus.

The series New Documents Illustrating Early Christianity ${ }^{11}$ is a fitting end-point, since it was originally proposed by Winter and brought to publication by Horsley, Llewelyn and others under the aegis of Judge. The series examines published papyri and inscriptions for their pertinence to the vocabulary and ideas of the New Testament. The series aims to introduce practising Biblical scholars to the variety and

10 T. W. Hillard, A. M. Nobbs and B. W. Winter, 'Acts and the Pauline Corpus I: Ancient Literary Parallels', in The Book of Acts in its First Century Setting, vol. 1: Ancient Literary Setting (Grand Rapids: Eerdmans, 1993): 183-213.

11 Volumes 1-7 published progressively by the Ancient History Documentary Research Centre, Macquarie University; and vols 8- by Eerdmans, Michigan. Vols 1-5 were edited by G. H. R. Horsley and vols 6- by S. R. Llewelyn. 
scope of these ever-multiplying documents, by having them reviewed by an ancient historian to sift out their significance for biblical studies.

Thus the integration of the biblical world and the classical one of the ancient historian becomes a reality in these volumes. Almost any page would demonstrate the point, but to take a well-known case, that of Philemon in relation to what we know of slavery in the Roman world, there is an easy juxtaposition of Pliny's evidence with that of Paul, with the addition of evidence from Suetonius and Cicero on the points at issue. ${ }^{12}$

Such cases show that, while there are no easy answers, the way forward for both biblical scholars and ancient historians lies in partnership between the classical and biblical, a not unsuitable prospect even for more modern dilemmas.

12 S. R. Llewelyn, New Documents Illustrating Early Christianity 8 (Grand Rapids: Eerdmans, 1998): 41-46. 